\title{
Fárveikir sjúklingar með inflúensu A (H1N1)v 2009 og skjót birting greina hjá Læknablaðinu
}

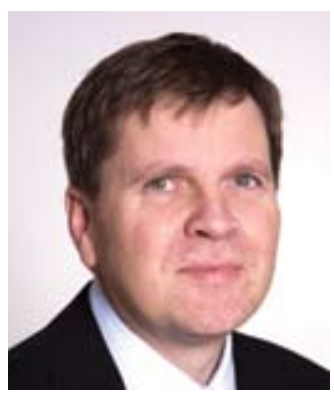

Gunnar Guðmundsson

ggudmund@landspitali.is

Sérfræðingur í lyflækningum, lungna- og gjörgæslulækningum og er i ritstjórn Læknablaðsins.
Pað hefur ekki farið fram hjá neinum að á seinni hluta ársins 2009 gekk faraldur inflúensu A (H1N1)v 2009 yfir Ísland og talið er að tugpúsundir manna hafi veikst. Fram fór fjöldabólusetning og tilfellum fækkaði mikið. Búist er við að faraldurinn geti farið aftur af stað á vormánuðum 2010 en verði mun vægari en síðasta hluta árs 2009 vegna fjölda bólusetninga sem framkvæmdar hafa verið. Síðastliðið haust veiktust nokkrir einstaklingar alvarlega af inflúensu og pörfnuðust innlagnar á gjörgæslu og sumir öndunarvélameðferðar. Gísli H. Sigurðsson og félagar segja frá pessum sjúklingum í grein í pessu tölublaði Læknablaðsins sem nefnist: Gjörgæslusjúklingar með inflúensu (H1N1) á Íslandi 2009. ${ }^{1}$ Petta voru 16 sjúklingar og var meðalaldur peirra 48 ár. Hluti hópsins var ekki með neina alvarlega undirliggjandi sjúkdóma en 13 einstaklingar reyktu, voru of pungir eða höfðu háprýsting. Tólf af sjúklingunum voru lagðir í öndunarvél og tveir fóru síðar í hjarta- og lungnavél. Enginn sjúklinganna lést á gjörgæslu en einn aldraður fjölveikur maður lést á gjörgæslu. Höfundar álykta að tíðni alvarlegra sjúkdómseinkenna á Íslandi sé há og einkennist af alvarlegri öndunarbilun sem láti ekki alltaf undan hefðbundinni öndunarvélameðferð. Ljóst er að starfsfólk gjörgæsludeild vann mikil afrek með pví að koma öllum pessum sjúklingum í gegnum petta erfiða sjúkdómsferli á pessum stutta tíma.

Pessar niðurstöður eru að sumu leyti svipaðar og pær sem sagt hefur verið frá í öðrum löndum. ${ }^{2-4}$ Höfundar bæta einnig við með grein sinni nýjum og mikilvægum upplýsingum um sjúkdómsgang og meðferð bráðveikra sjúklinga með inflúensu A (H1N1)v 2009. Eins og Gísli og félagar benda á er ekki ljóst af hverju tíðni alvarlegra einkenna er hærri á Íslandi en í Ástralíu, Nýja-Sjálandi og Kanada miðað við höfðatölu. Hugsanlega skýringu telja peir geta verið að um sé að ræða hlutfallslega stærri faraldur, en erfðafræðilegir pættir gætu líka skipt máli. Petta gæti verið fróðlegt að rannsaka nánar.
Eins og sjá má í lok greinar Gísla og félaga leið stuttur tími frá pví greinin var send til Læknablaðsins og par til hún var sampykkt til birtingar og hún birtist svo á prenti. Eins leið stuttur tími frá pví sjúklingarnir voru inniliggjandi og par til búið var að draga saman niðurstöður um pá og koma saman í grein. Tilskilin leyfi fengust einnig fljótt fyrir rannsókninni hjá Vísindasiðanefnd og lækningaforstjóra Landspítala og hún var tilkynnt til Persónuverndar. Hér gengu pví margir pættir mjög fljótt fyrir sig. Hér hafa fengist mikilvægar upplýsingar sem geta nýst heilbrigðisyfirvöldum til að gera frekari ráðstafanir vegna inflúensunnar og nýtast læknum sem annast sjúklinga til að veita peim bestu mögulegu meðferð. Án efa mun greinin verða mikið skoðuð erlendis í gegnum pá gagnagrunna sem Læknablaðið er nú skráð í pví hún gefur mikilvægar nýjar upplýsingar fyrir heilbrigðisyfirvöld og lækna um allan heim.

Ritstjórn Læknablaðsins stefnir að pví að bjóða höfundum upp á hraðari ritrýni og styttri tíma frá innsendingu til birtingar greinar í völdum tilvikum. Petta á sérstaklega við í tilvikum eins og hér pegar verið er að birta upplýsingar um alvarlegan sjúkdóm sem ekki eru miklar upplýsingar til um áður á alpjóðavísu. Peir sem hafa áhuga á að birta greinar í Læknablaðinu ættu að kanna pennan möguleika pegar peir eru að íhuga val á tímariti til birtingar á nýjum og mikilvægum niðurstöðum, hvort sem um er að ræða grunn- eða klínískar rannsóknir.

\section{Heimildir}

1. Sigurðsson GH, Möller AD, Kristinsson B, et al. Gjörgæslusjúklingar með inflúensu A (H1N1)v á Íslandi 2009. Læknablaðið 2010; 96: 83-90.

2. Domínguez-Cherit G, Lapinsky SE, Macias AE, et al. Critically ill patients with 2009 influenza A (H1N1) inMexico. JAMA 2009, 302: 1880-7.

3. The ANZIC Influenza Investigators. Critical Care Services and 2009 H1N1 Influenza in Australia and New Zealand. N Engl J Med 2009; 361: 1-10.

4. Kumar A, Zarychanski R, Pinto R, et al. Canadian Critical Care Trials Group H1N1 Collaborative. Critically ill patients with 2009 influenza A(H1N1) infection in Canada. JAMA 2009; 302: 1872-9. 